ISSN No. 0974-035X

An Indexed, Refereed \& Peer Reviewed Journal of Higher Education

Towards Excellence

UGC-HUMAN RESOURCE DEVELOPMENT CENTRE,

GUJARAT UNIVERSITY, AHMEDABAD, INDIA

\title{
DALITIZING THE NATION: COUNTER-CULTURE IN THE POETRY OF
} MEENA KANDASAMY

\section{Ms. Pratibha Biswas}

\section{Abstract}

In reference to Partha Chatterjee's explication of 'the nationalist resolution of the women's question'; M.S.S Pandian retorts, revealing the implication for the subaltern classes that, " [e]lite Indian nationalism scripted the story by working through the binaries of spiritual/material, inner/outer and valorizing the inner or spiritual as the uncolonised site of national self-hood. . .[..] This act of mobilizing a part of the national to stand for the whole, not only inferiorised vast sections of lower castes as inadequate citizens-in-the-making, but also significantly delegitimized the language of caste in the domain of the politics by annexing it as part of the cultural"'(395).

In tandem with Dalit assertion, Meena Kandasamy's polemical poetry reveals the tenacious presence of caste within the 'modern secular national public sphere', exposing the chauvinistic orientation of the Hindutva inspired yet unmarked nation by critiquing the codified and naturalized Brahmanical discourse. The paper attempts to explicate that Kandasamy's poetry published in Touch (2006) and Ms. Militancy (2010) contests nationalist discourse from Dalit perspective and represents, 'the nation split within itself'. 
Towards Excellence: An Indexed, Refereed \& Peer Reviewed Journal of Higher Education / Ms. Pratibha Biswas / Page 49-66

Post- 1947 conceptualization of caste as the foundational principle of Hindu-Indic social structure framed within the religio-cultural framework, as articulated by Luis Dumont in Homo Hierarchicus (1970), led to it being associated with 'tradition' and 'backwardness'; a hindrance to the process of India's coming into Nehruvian model of nation-state based on socialism, secularism and development. As Debjani Ganguly notes, it came to be regarded, "as a relic of India's pre-modernity . . . but something that would eventually lose potency as principle and practice of social organization" (5). In the early decades after independence, much of the social scientific knowledge about caste was culled from the genre 'village studies' based on detailed ethnographic accounts of life in villages through participant-observation approach; this strand of conceptualization being represented by M. N. Srinivas. But since this approach focused primarily on rural sites for fieldwork, along with the relative rarity of urban case studies, it consequently led to the entrenchment of the view that caste is predominantly a rural phenomenon distanced from the urban middle class milieu. The year 1990, with the union government's belated decision of implementation of the recommendations of the Mandal Commission following the agitations against it; is considered a watershed year in the epistemology of caste, for it marks a definitive shift in the perspective of modern Indian intellectuals. Vivek Dhareshwar in "Caste and the Secular Self" purports that before Mandal, caste as a category for critical reflection had been intellectually repressed and banished out of the narrative of the secular self to rural society or traditional past. The mobilization that followed the decision of implementation of Mandal Commission rejuvenated the caste question with the re-implication of upper caste self into it. But certain attributes of caste as a practice, continue to be used by the some so called urban middle class secular citizens in metonymic fashion vis-à-vis caste; such as untouchability and reservations; truncating its complexity as an institution and obliterating aspects like 'atrocity' 
Towards Excellence: An Indexed, Refereed \& Peer Reviewed Journal of Higher Education / Ms. Pratibha Biswas / Page 49-66

and 'intra-dalit strife,' or 'economic disparity and discrimination'; so much so that the abolition of untouchability gets equated with the abolition of caste system (5).

Ganguly in the book, Caste and Dalit Lifeworlds: Postcolonial Perspective (2005), attempts a postcolonial reading of caste and calls Ambedkar, 'modernity's interlocutor for Dalits', as reflected in his engagement with colonial modernity and Indian nationalism. She remarks that his analysis of caste was constructed within the discursive structure/horizon of Orientalism, but it can be ascertained, "[f]rom our retrospective theoretical advantage over him-he had no postfoundationalist philosophers to fall back on" and though he did make caste and untouchability the key problematic of Indian society, seeing purity/pollution axis as its cornerstone, yet he primarily read these categories through the idiom of power (63-84). M.S.S. Pandian makes an intervention in the debate about Ambedkar and modernity, in "One Step Outside Modernity: Caste, Identity, Politics and Public Sphere" and argues that the politics of Ambedkar and Phule were oriented toward criticism of the nationalist construction of modernity that banished caste out of the public sphere of politics, so its invocation was decried as sectarian and pro-British. In reference to Partha Chatterjee's explication of 'the nationalist resolution of the women's question'; Pandian retorts, revealing the implication for the subaltern classes that, "[e]lite Indian nationalism scripted the story by working through the binaries of spiritual/material, inner/outer and valorizing the inner or spiritual as the uncolonised site of national self-hood. . .[...] This act of mobilizing a part of the national to stand for the whole, not only inferiorised vast sections of lower castes as inadequate citizens-in-the-making, but also significantly delegitimized the language of caste in the domain of the politics by annexing it as part of the cultural" (395). It can be argued that since, Dalit intellectuals, ideologues and writers continue to treat theoretical paradigms advocated by Ambedkar as the wellspring for their 
revolutionary ideals; we see the tropes of 'nation,' 'citizenship,' 'equality,' 'democracy' and 'rights' continue to configure the narratives of caste in present times. Yet, one also finds in Dalit narratives and literature the disillusionment with the functioning of postcolonial nation-state and an awareness of the discursivity and contingency of categories such as 'nation' and 'history.' Their inquiry of the grand narratives hinges upon the questions of power and domination, to reveal the discontinuities, fragmentation and disruption. This two-pronged move has posed a problematic to postcolonial thought to come to terms with Dalit assertion. Sharankumar Limbale, in a highly subversive gesture explodes the binary of colonizer-colonized framework within which much theorizing of the postcoloniality and subalternity is articulated, to expose how a subjugated society can simultaneously be a subjugating society. In Towards an Aesthetic of Dalit Literature: History, Controversies and Considerations (1996) he explicate the different nature of Dalit's alterity; which is inherited from birth and sanctioned by sacred authority, therefore being spatial as well as normative; making Dalits the upper caste Hindu's 'Other'. "But this 'Other' is not only separate and different, like member of another ethno-cultural, religious or linguistic group. This 'Other' is the part of Hindu society and [yet] apart from it" (2). Limbale purports that the need, role, content and form of Dalit literature comprise the answer to Gayatri Chakravorty Spivak's seminal question- 'Can the subaltern speak?' Nina Caldeira attempts an elucidation of Dalit literature, reading it through the power/knowledge paradigm purported by Michel Foucault in Archaeology of Knowledge, in her article " The Subaltern Speaks: Politics and Poetics of Dalit Literature" to argue that "[t]he dalit writer enters the archeology of the Verna system to fill its 'other', its 'discontinuities' and its 'differences' and "by extension on the national space, dalit consciousness fragments and disrupts the discourse of history" (77). In tandem with Dalit assertion, Meena Kandasamy's polemical poetry exposes the tenacious 
presence of caste within the 'modern secular national public sphere', revealing the chauvinistic orientation of the Hindutva inspired yet unmarked nation by critiquing the codified and naturalized Brahmanical discourse. The paper attempts to explicate that Kandasamy's poetry published in Touch (2006) and Ms. Militancy (2010) depicts caste as 'a traditionaliser and a moderniser' at once. As purported by Rajni Kothari, caste is capable of 'secular upsurge' against religious communalism. "Caste can be oppressive but it can also provide a basis for struggle against oppression" (65). The paper also enunciates that Kandasamy as a poet subverts nationalist discourse from Dalit perspective and represents, what Homi Bhabha refers to as a 'nation split within itself'.

"Meena Kandasamy is a feisty new entrant into the duck pool called Indian English poetry", opines Anjum Hasan. A champion of Dalit rights, she is known for her subversive writing imbued with militant spirit and voice of dissent against casteist mindset as well as gender oppression. Unlike other Dalit writers, who reject the standard language, which they feel smacks of class, and write predominantly in vernaculars, Kandasamy writes in English. She rejects the labeling of her writing as parallel or alternative and proposes that "the so called mainstream is something that has been hijacked by an elite minority. . . . The real India, crumbling under its caste system and corruption, isn't present in their writing. . . [V]oices of women and men from the oppressed castes and minority will give credibility to the mainstream" (Kandsamy). Influenced by the translated poems by Marathi Dalit poets and the African- American poets, she writes poetry to militate against caste oppression.

For Kandasamy, "[a]ggression is the best kind of trouble shooting" (Touch 38). Hasan, observes; "[a]nger is the engine of Kandasamy's poems and she is even more effective when the anger ripens into sarcasm". I read her poetry, not as an incitement to take cudgels in hands but 
perhaps a call for mobilizing the Dalit consciousness. As in the poem "Aggression" she reinstates the agenda of Dalit assertion:

Our is a silence

that waits. Endlessly waits.

And then, unable to bear it

any further, it breaks into wails.

But not all suppressed reactions

end in our bemoaning the tragedy.

Sometimes the outward signals

of inward struggles takes colossal forms

And the revolution happens because our dreams explode. (1-10)

One can discern the echo of Langston Hughes' poem, "A Dream Deferred" in the phrase 'dreams explode'. Reminding the reader of the Cultural Revolution brought about by black artists in 1930s, known as the Harlem Renaissance. Raj Gauthaman in his article "Dalit Protest Culture: The first Stage" argues that; [t]he Dalits, who are steeped in guilt, fear, despair, poverty, centuries of ignorance, slave mentality, and apprehensions of change, will find it difficult to free themselves from this [servile] mindset. Only by ignoring, attacking, humiliating, rejecting this hegemonic culture, its symbols step by step, can the Dalits get rid of their mental blocks" (264). In line with this, Touch and Ms. Militancy contain several poems that offer discursive resistance through unapologetic diatribe against Brahmanical ethos that have become entrenched and 
naturalized. For instance, Kandasamy's bitterly caustic poem "Reverence:: Nuisance" directs vituperative opprobrium toward Hindu gods, for their inability to prevent people from soiling their posters with spit and urine; adorning roadside walls, "staircases of offices, hospitals, and other "secular institutions"” (Touch 72). It ends with an evaluative claim that, "the Caste Gods deserve / the treatment they get" (19-20). The poem highlights the ubiquitous presence of predominantly Hindu mythical icons in the so called 'secular public places', bringing to light the dominance of Hindutva ideology within National symbolic space. It also insinuates a critique of the majoritarian trend of defining Hindutva as a way of life in India; the sentiment made explicit in RSS Chief Mohan Bhagwat's statement that "India is a Hindu Nation and Hindutva is its identity, and it can incorporate others." Another fitting example is the Gandhian notion of Ram Rajya that has been blatantly distorted, even used for canvassing before elections on religious lines and appropriated in communal context by politicians for defining post-independence Indian state essentially in Hindu terms, extolling the Hindu god for moral living and righteous polity. The flip side of this legitimizing logic is that groups that are denied space or visibility in national arena get delegitimized and marginalized. As Gail Omvedt, in the preface to Dalit Visions cites:

In destroying the Babri Masjid on December 6, 1992, the forces of Hindutva issued a declaration of caste war, not simply an assault against the Muslim community. The act and the statements surrounding it made it clear that the VHP, Shiv Sena and sections of BJP were not prepared to respect the decisions of the courts or the laws of the land regarding the "birthplace of Lord Ram" and that the "Dharma Sansad" was being posed as higher than the people's parliament. This was a declaration of war against dalits, adivasis, women, the bahujan samaj, the toiling and productive castes and classes who have always been held as inferior by varnashrama dharma. That war has to be fought, at 
Towards Excellence: An Indexed, Refereed \& Peer Reviewed Journal of Higher Education / Ms. Pratibha Biswas / Page 49-66

the level of culture and symbolism and not simply with weapons of "secularism" but over every inch of the terrain of Indian history and identity that the Hindu-nationalists have staked a claim to. (viii)

Under the Hindutva appeal to the glorious past and the mythic unity of the Hindu people, demanding homogeneity, the oppositional voices that do not fit in the teleological narrative, either get subsumed or silenced. Registering the despondence for the loss of history/past of Dalits and the fugacious nature of memories, Kandasamy in her poem "Fleeting" bemoans in Spivikian note : "[o]ur history is lost, / perhaps destroyed / [a]nd efforts at recollection / [e]ntail in melancholy. /And fleeting memories are perishable- / Imaginary showcase stuff having expiry dates" (1-6). Without mincing words, Kandasamy articulates dissent against aforementioned homogenizing tendency in defining the 'national culture' to reveal a "nation split within itself" (Bhabha 148). In her poem "Mohandas Karamchand," she undermines the exultation of Gandhi as a symbol of Indian nationalism. The sentiment of resentment that Dalits harbor against Gandhi for his ambivalence on the question of caste, and for eulogizing the varnashramadharma as immanent, is too well known. Anjum Hassan observes:

One of the best poems in the collection... [ is] a lampooning of Gandhi via Sylvia Plath. A perfect echo of Plath's "Daddy", the poem shows how persuasiveness in poetry is as much a matter of cleverness with language as having a well meaning agenda. Whatever one feels about Gandhi, lines such as the following do their work: "You need a thorough review / Your tax free salt stimulated our wounds / We' re gonna sue you, the Congress shoe" and "You dubbed us Pariahs—Harijans"/ Goody goody guys of a bigot god/ Ram Ram Hey Ram -Boo". 
In the same vein, the poem "Emergency" recounts the anti-reservation stir by medicos of AIIMS, beginning in April 2006 that snowballed into nation- wide protest against reservation quota for OBC. Subverting the rhetoric of 'merit', the lines allude to the post Mandal debate, which precipitated an important break in Indian politics, since caste discrimination got reconfigured into the rhetoric of 'national interest,' 'merit' and 'efficiency' by anti-reservationist who represented themselves as 'secular' and 'modern citizens' and labeled those who publically invoked caste by asking for caste based reservations as casteist. The resurgence of caste was condemned as "revival of outmoded forms by politicians playing to masses" (Tharu 12) and the argument was extended to not only oppose caste based reservations but also inadvertently negate the tangible presence of caste as vector of marginalization for SC/ST/ OBC/ Dalits, in contemporary times. Kandasamy writes thus:

Since reservation in education

is a calamitous emergency,

brahwoman medicos press their point.

Moving over 24-hours news channels

health divas empty out the hospitals.

But elsewhere, their lowercaste sisters

continue their professional practice. ( 13-19)

By naming the protestors as 'brahwoman' Kandasamy demystifies the fiction of the 'general category' used as a euphemism for upper caste candidates; revealing how the term disguises in its anonymity a severely unequal access to privilege; since, "[h]aving encashed its traditional 
caste-capital and converted it into modern forms of capital like property, higher educational credentials and stronghold in lucrative professions, this section believes itself to be 'caste-less' today (Deshpande 402). The poem chronicles the agitations against reservation that have been equally vociferous as the mobilizations for it, but inverts the images; of the upper castes who call themselves the aggrieved victims of reservation policy, portrayed as aggressors and Dalits who are generally decried as inefficient, depicted as meritorious. Likewise, in the poem "One eyed" she recounts the entrenched intolerance and discrimination rampant in educational institutions. The ramifications of which, become conspicuous in inordinate number of Dalit students either dropping out or in extreme cases committing suicide. The poem brings out the anguish of an untouchable student who is at the receiving end of virulent caste prejudice; unjustly rendered corporal punishment for the harmless act of satiating her thirst, in the following words: "dhanam sees a world torn in half. / her left eye, lid open but light slapped away,/ the price for the taste of that touchable water" (8-10).

K. Balagopala in the essay "This Anti-Mandal Mania", lambastes the monopoly of forwardcaste Hindu, holding top positions in administration, education, science, technology and medicine, explicating the use of 'right connections' as another reservation prevalent in Indian society, thus:

Tickets to the assembly or Parliament at election time, public works and excise contracts, co-operative loans, industrial licenses, supply contracts, managerial jobs in the private sector, a vice-chancellor's post, or even a favoured relation with faculty of universities. . . not one of these is obtained without the use of caste. . India's elite; the propertied classes uses their caste to maintain and reproduce their status, as to acquire commensurate political power. (219) 
Towards Excellence: An Indexed, Refereed \& Peer Reviewed Journal of Higher Education / Ms. Pratibha Biswas / Page 49-66

Since, the 'general category' posits itself as 'the unmarked citizen' or 'caste-less' this 'encashment of caste' remains elusive because it is often told as the 'story of nation building', 'great tradition modernizing itself' or that of globalization (Deshpande 404-405). Kandasamy interrogates this unilateral idea of progress/nation building in her poem "Inheritance" in the context of land acquisition by government, rupturing the narrative by depicting the discordant voices of poor, displaced for such development projects.

Helplessly, silent;

we watched it being seized away, all our lands.

The Government- a fulltime bewitching whore

had promised Jobs. Industrialization. Power. Electric.

Everything went, Nothing came.

Now, landless, uprooted,

unsettled in a resettlement colony

we feast our souls on lucent memories -of an earlier life. (1-8)

Correspondingly, her poem "Fire" reminiscent of Kilvenmani carnage exposes the nexus between the state agencies and the upper castes, bringing out, what Pramod Nayar describes as, the 'post-colonial subalternization' of Dalits. Depicting the catastrophe of burning of Dalit shanties, as an orchestrated tragedy, Kandasamy brings out the vulnerability and hapless condition of the impoverished. They are as defenseless "as snail shells crackling under nail boots" (Kandasamy), succumbing to mass slaughter, due to the conniving designs of the affluent. 
The line "Fire engines arrive / Deliberately late", "when the blazing work is done" suggests conspiracy (14-16). The incident of Jhajjar in Haryana that occurred on 15 Oct 2002, when caste Hindus lynched five Dalits in broad day light, within the police premise, with the police officials being mute witnesses, or that of Bhutegaon in the Marathawada region of Maharashtra in May 2003, where a Dalit youth was burnt alive by caste Hindus; even the case of atrocity that occurred in Khairlanji; stand testimony to the fact that acts of brutality continue to be perpetrated upon Dalits (Teltumbde 233). The increase in the number of such ghastly incidents is interpreted as backlash form upper castes in the face of Dalit assertion, who use violence to safeguard their entrenched superior status or to crush transgression.

Suffused with tales of woe, as well as hope, Kandasamy's poems seek to bring about a revolution, as evident in the lines of her poem, "We will rebuild worlds". The sentiment resonates in the poem, "We real hot (Inspired by We Real Cool by Gwendolyn Brooks)."

We real hot. We

Ne'er rot. We

Know knack. We

Beat back. We

Shock stars. We

Win wars. We

Ne'er late. We

Fuck fate. (1-8) 
Using a few well placed words, Brooks conveyed the boldness and insecurity of a bunch of young boys, spending their day in a dingy pool hall rather than being at school and their sense of pride in defying conventions. Kandasamy uses the poem as mould to express the new found confidence of Dalits, who have begun to assert pride in their Dalit identity. They are the speaking subjects, not afraid to show their resentment at the injustice done to them; they retaliate, counter attack, confront discrimination and defy providence to instate a counter-culture. They are not the liberal-reformist upper caste authors' often romanticized, ineffectual characters.

In conclusion, it can be said that, Kandasamy's poetry gives contemporaneity to caste, revealing that rather than being "a remnant of pre-modern hierarchical purity pollution formation specific to Hindu religion" (Satyanarayan and Tharu 9), it is a live force in Indian cultural politics. Problematizing the discourse on amelioration of poverty, progress and modern nation building by juxtaposing the ubiquitous presence of caste in the body politic of the nation state with its corporeal presence in Dalit everyday experience, Kandasamy represents caste in its multivalence. In her reformative zeal; at times mutinous, at times moving; she appears to be an 'organic intellectual' in the Gramscian sense, who is actively engaged in exposing; the chauvinistic orientation of the Hindutva inspired, yet unmarked nationalism and the hegemony of the upper castes/elite upon so-called sovereign domain of national culture. The 'nation' is represented as a contentious terrain; imbued with the cacophony of contending voices. The tropes of 'past,' 'memory,' 'history' and 'dignity' that have become a staple in the narratives of Dalit assertion are rearticulated, maintaining the continuum of dissipation of emancipatory Ambedkarite thought, which remains a preoccupation of Dalit literature. But Kandasamy, even in singing the worn out song of Dalit protest, kindles new vigour and perspective in it, by bringing the hitherto (literally and figuratively) 'domesticated' category of women, to the center . 
For instance, in her poem, "Emergency," it is women who are shown thronging the streets in anti-Mandal agitation, shouting slogans and braving the canons, exposing the complicity of upper caste women in the maintenance of hierarchy. On the other end too, we find the lower caste women as Doctors debunking the rhetoric of meritocracy by continuing their professional practice as; Gastroenterologist, Pulmonologist, Pediatrician, Cardiologist, Endocrinologist and so on, proving their 'merit'. Correspondingly, Dalit woman is depicted as an 'agentive subject' resisting subjugation in her poem, "Liquid tragedy: Karamchedu 1985," though she does succumb to casteist violence ultimately. Dalit girl is also shown at the receiving end of discrimination in her poem "One eyed." It can be deduced that her poems are an attempt at, what Uma Chakravarti calls, "gendering caste through a feminist lens" (the title of her book). But even in the gendered perspective on caste she privileges the polemical "Dalit vision" which is "Dalit realist" (Gajarawala 18) in its orientation and characterizes "prescriptive militancy" (Rai 154). 
Balagopal, K. “This Anti- Mandal Mania .” Deshpande 215-232.

Bhabha, Homi. The Location of Culture. New York: Routledge, 1994. Print.

Caldeira, Nina. "The Subaltern Speaks: Politics and Poetics of Dalit Literature.” Writing as Resistance: Literature of Emancipation. Ed. Jaydeep Sarangi. Delhi: GNOSIS, 2011. Print.

"Cultural Identity of All Indians is Hindutva" The Times of India 10 Aug. 2014: n.pag. Timesofindia.com Web. 16 Aug. 2016.

Dhareshwar, Vivek. "Caste and the Secular Self”, Journal of Arts and Ideas, 25-26,1993, 115-126. Web. 24 August 2016.

Deshpande, Satish. Introduction. The Problem of Caste : Readings on the Economy, Polity and Society. Ed. Deshpande. New Delhi: Orient Blackswan Private Limited, 2014.

Print.

---. "Caste and Castelessness: Towards a Biography of the 'General Category"”. Deshpande 402-410.

Gajarawala, Toral Jain. Untouchable Fictions: Literary Realism and the Crisis of Caste. New York: Fordham University Press, 2013. Web. Google Book Search. 18 June 2015. 
Ganguly, Debjani. Caste and Dalit Lifeworlds: Postcolonial Perspectives. New Delhi: Orient

Blackswan Private Limited, 2005. Print.

Gauthaman, Raj. “Dalit Protest Culture: The First Stage.”The Oxford India Anthology of

Tamil Dalit Writing. Ed. R. Azhagarasan and Ravikumar. New Delhi: Oxford

University Press, 2012. 263-274. Print.

Hasan, Anjum. “Anger is the engine of Kandasamy's poems.” Rev. of Touch, by Meena

Kandasamy. The Hindu. com. 3 June 2007. Web. 22 Nov 2014.

Kandasamy, Meena. Interview by Ujjwal Jana. “The Struggle to Annihilate Caste will be

Victorious.” Postcolonial Text 4.4(2008): n. pag. Web. 13 Sep. 2013.

---. Ms. Militancy. New Delhi: Navayana, 2010. Print.

---. Touch. Mumbai: Peacock Books, 2006. PDF file

Kothari, Rajni. "Rise of the Dalits and The Renewed Debate on Caste." Deshpande 63-70.

“Modi's Ram Rajya Remarks No Violation of Law: BJP.” Rediff.com. n.d. Web.15 Aug. 2016.

Tharu, Susie and K. Satyanarayan. Introduction. No Alphabet in Sight. Ed. Tharu and Satyanarayana. New Delhi: Penguin Books, 2011. Print. 
Towards Excellence: An Indexed, Refereed \& Peer Reviewed Journal of Higher Education / Ms. Pratibha Biswas / Page 49-66

Teltumbde, Ananad. “Khairlanji and Its Aftermath.” Deshpande 233-241.

Limbale, Sharankumar. Towards an Aesthetic of Dalit Literature. Trans. Alok Mukherjee.

Delhi: Orient Blackswan Private Limited, 2010. Print.

Omvedt, Gail. Dalits and the Democratic Revolution: Dr. Ambedkar and the Dalit Movement in Colonial India. New Delhi: Sage Publication, 1994. Print.

Pandian, M.S.S. “One Step Outside Modernity.” Deshpande 393-401.

Rai, Alok, "Poetic and Social Justice: Some Reflections on the Premchand- Dalit Controversy."Justice: Political, Social, Juridical. Ed. Rajeev Bhargava, Michael Dusche and Helmut Reifeld. New Delhi: Sage Publications Pvt. Ltd, 2008. Print. 
Towards Excellence: An Indexed, Refereed \& Peer Reviewed Journal of Higher Education / Ms. Pratibha Biswas / Page 49-66

\section{AUTHOR INFORMATION:}

Pratibha Biswas is currently a research scholar at the Dept. of English, Jamia Millia Islamia University, New Delhi and teaches English language and literature at, Sharda University, as Assistant Professor in the School of Languages and Culture. She completed her B.A. from Delhi University, M.A. from Annamalai University and M. Phil. from Dept. of English, Jamia Millia Islamia University. Her areas of interest include Indian Literature in English, Dalit Literature, Women's Writings and Contemporary Indian Poetry in English. Her research papers have appeared in two issues of Muse India and in other reputed journals. She enjoys reading and writing poetry and her poems have appeared in Open Road Review, an international literary ejournal and The Brown Critique, a critically acclaimed literary quarterly and the Earthen Lamp Journal.

\section{Pratibha Biswas}

\section{Ph.D. Research Scholar, Dept. of English,} Jamia Millia Islamia University, New Delhi pratibhabiswas85@gmail.com

(M) 9953232334 